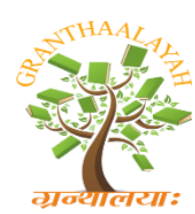

INTERNATIONAL JOURNAL OF RESEARCH GRANTHAALAYAH A knowledge Repository

Social

\title{
COALITION REGIME AND INDUSTRIAL POLICY IN JAMMU AND KASHMIR: AGRO-BASED INDUSTRY IN BARAMULLA DISTRICT OF J\&K STATE
}

\author{
GH MOHD SHEIKH *1 \\ ${ }^{*}$ Phd Student, Department of Political Science, SOSS, Indira Gandhi National Open University \\ (IGNOU), New Delhi, India
}

DOI: https://doi.org/10.29121/granthaalayah.v5.i6.2017.2053

\begin{abstract}
Since 2002 political structure of the state of Jammu and Kashmir underwent a paradigm shift. A coalition era has deepened its roots in the state politics. PDP and Congress joined the governance of the state as a coalition regime in the year 2002. This coalition regime has brought up the various development policies; one among them was the industry policy which was formulated in the year 2004. Under the policy, food processing including agro-based industry was one among the main thrust areas. Similarly, in the paper an attempt has been made to analyze the factors which were responsible for the formulation of industry policy. In particular, the paper explores the agro-based industry of the Baramulla district in terms of removal of regional disparities/imbalances which exists between three regions of the State.

The research paper argues that Kashmir region has widely neglected in terms of industry development while the Jammu region has been given special importance before and after the coalition regime of PDP-Congress (2002-2008).

Keywords: Coalition Regime; Industry Policy; Agro-based Industry; Jammu and Kashmir.

Cite This Article: GH MOHD SHEIKH. (2017). "COALITION REGIME AND INDUSTRIAL POLICY IN JAMMU AND KASHMIR: AGRO-BASED INDUSTRY IN BARAMULLA DISTRICT OF J\&K STATE." International Journal of Research - Granthaalayah, 5(6), 437-446. https://doi.org/10.29121/granthaalayah.v5.i6.2017.2053.
\end{abstract}

\section{Introduction}

Since the Instrument of Accession of the state of Jammu and Kashmir with the Union of India, the state of Jammu and Kashmir has been dominated by the single state political party-National Conference with some breaks by the Indian National Congress. However, in 2002 political structure of the state of Jammu and Kashmir underwent a paradigm shift. The central government made an attempt to go for the free and fair election in the state. This commitment brought up the hung assembly, strong opposition, coalition government, and emergence of a new 
regional party known as the People's Democratic Party (PDP). The PDP was formed in the year 1999 by the late Mufti Mohammad Syed. In 2002 Assembly elections, it contested almost from all three regions of the state but had won 16 seats from Kashmir region only. Similarly the Congress party won 21 seats from Jammu region. However, the National Conference emerged as the single largest party with 28 seats $^{1}$, but chose to be in opposition. After the election results the PDP and Congress governments joined hands to form a coalition government in the state of Jammu and Kashmir with the help of some small state political parties and independent candidates in November 2002 (Chaudary, R. 2016).

The coalition government (PDP-Congress) drafted a Common Minimum Programme (CMP), with regional development as the core issue and to ensure that all three regions of state- Jammu \& Kashmir and Ladakh- would obtain an equitable and evenhanded share of resources for development. The two coalition collaborators agreed to head the government for three years each of six years tenure of the state of Jammu and Kashmir Assembly. First three years of the coalition government was handed over to the People's Democratic Party (2, November 2002 - 2, November 2005) and another full three years was supposed to take the Congress Government (2, November 2005 - 2, November 2008). However, Congress Government fell short of completing its three years tenure and reigned only up to $11^{\text {th }}$ July 2008, mainly because of Amarnath land row.

To achieve the objective of CMP, the state government under the leadership of Mufti Mohammad Syed, drafted a first detailed industry policy with the main objectives; a) To achieve sustainable industrial development in all regions of the state for increasing the value of output and employment; and b) To strive towards balanced economic and social development in all regions of the state by promoting industrialisation, particularly of the industrially backwards areas. The 2004 industrial policy has mentioned various thrust areas. Similarly, food processing including agro-based industries (excluding conventional grinding/extraction units) is one among the main thrust areas.

\section{Methodology}

Baramulla District of Kashmir region of the State of Jammu and Kashmir was selected for field work for agro-based industry policy. Primary Data was collected from the JKSIDCO, DIC Baramulla, Managing and Assistant Managing Director, Industrial officers and Entrepreneurs of Baramulla district. The local employees of the concerned area have also been taken into consideration for the further improvement of data research. The secondary data was collected from Economic Surveys of Jammu and Kashmir, Industry Policy of 2004, Books, Journals and Internet Sources.

\section{Objectives}

The present study is based on the following objectives: -

1) To explore the factors responsible for the formulation of the agro-based industry.

2) To analyze the agro-based industry of the Baramulla district. 


\section{Literature Review}

During the past two decades a significant amount of work has been done on the industrial policies of India. However, not much work has been done on the coalition government and industry policy with special reference to agro-based industry, which would have focused on the regional development of the state of Jammu and Kashmir. The limited literature on the subject has been briefly categorized into two sections: - 1) literature in general and 2) literature deals with the state of Jammu and Kashmir

Literature in general holds that, India has a small agro-based food processing sector. However, the country has a strong base of agriculture on the one hand but on the other hand the wastage is quite high. Despite this, country exports about 1.5 percent of the food processing products in the world trade (Kumar, R. S 2014). Similarly, Asstt. Director General (Process Engineering), Indian Council of Agricultural Research, New Delhi, Kachru, R. P, has analyzed the agro-processing sector and states the view that "Some estimates suggest that in developed countries, up to 14 per cent of the total work force is engaged in agro-processing sector directly or indirectly. However, in India, only about 3 per cent of the work force finds employment in this sector revealing its underdeveloped state and vast untapped potential for employment. Properly developed, agroprocessing sector can make India a major player at the global level for marketing and supply of processed food, feed and a wide range of other plant and animal products". However, Reddy, C. L and S. Rathna, K (2014) have highlighted the performance of agro-based industries in India and holds the view "The share of all agro-based industries in India account for 35.3 per cent of the total industrial units in India 40.32 per cent share of total employment and 21.69 of the total value of industrial output, and 15.18 per cent of the net value added during the year 2010-11. The percentage of working capital, fixed capital and net income of agro-based industries to total industries is 21.26 per cent, 20.3 per cent and 13.96 per cent respectively". Similarly a section of the literature deals with the role of agro-based industries in the rural development (Shejal, S. S 2013).

Literature on the state of Jammu and Kashmir states that despite the flow of hefty funds by the central government to the state, all three regions of the state- Jammu, Kashmir and Ladakh remain underdeveloped. This literature can be categorized into the following groups; one, it deals with the under development of the Jammu and Kashmir in a general way (Verma, 1987). Second, this deals with the Inter or Intra-Regional disparities in all three regions of the state (Malik, F. A and Bilal A. M, 2012; Mohiuddin, S and Hashia, H. 2012). Third, with special reference to the agro-based industry sector, the literature holds the view that, the state of Jammu and Kashmir is at the infancy stage in the agro-based industry despite the huge potential (Rather, N. A, et al, 2013; Hassan, S.U et al, 2015).

\section{Factors Responsible for formulation of Industry Policy}

\subsection{Insurgency Period}

The Insurgency period in the Kashmir region started in the year 1989. It has two broad periods; one 1989 to 20002 and second from 2002 to present. However, in the first period, the Industry sector of the Kashmir region suffered the most ${ }^{2}$. In the second period, the Central government 
industrial package of 2002 and state governments regional development initiative made a significant change in the industrial scenario of the Kashmir region. The central governments package had developed the culture of awareness and promotion of industrial units. However, the state government in 2004 came up with a first detailed industrial policy, with the main emphasis of regional development.

\subsection{Industrial Backwardness}

In general the state of Jammu and Kashmir is industrial backward state where as the Kashmir region is the most backward region of the state of Jammu and Kashmir in particular. Earlier the state government had come up with the industrial policies like 1995 and 1998, but they could not play a sufficient role in the development of industry in the state or the Kashmir region. Through the proper negligence of the government, the state industrial sector status was going down. This resulted to large industrial sickness in the state in general and in the Kashmir region in particular. According to the Economic Survey report of Jammu and Kashmir (2013-2014), the percentage of the Kashmir region is highest than the Jammu region. The Jammu region has $19.47 \%$ industrial sick units where as the Kashmir region percentage is $80.52 \% .^{3}$

\subsection{Growing Regional Disparity}

Regional Disparity is a significant issue in the state of Jammu and Kashmir. However, with regard to industry the gap was increasing between the three regions of the state since the decades. Jammu region had been flourished from each side while the Kashmir and Ladakh region had neglected. The same view holds by the President of Federation Chamber of Industires Kashmir in an interactive program organised by Kashmir Small Scale Industries Association (KSSIA) at Baghi Ali Mardan Khan, Srinagar city. He "informed that more than 95 percent of the incentives in J\&K state under Central Industrial Package- 2002 had gone to the units of only two districts of Jammu leaving remaining 5 percent for rest of 20 districts including 10 districts of the valley...over a period of past 25 years, the state government fully ignored the development of industrial infrastructure in the valley and by now Kashmir has less than 7000 Kanals of developed industrial plots as against more than 21000 Kanals of developed industrial plots in Jammu",

\subsection{Poor Entrepreneurial Culture}

According to renowned economist T.N. Srinivasan, 'India has been an entrepreneurial society...we had the entrepreneurial skill but suppressed it for too long a time... and now it is thriving" . However, in the state of Jammu and Kashmir, there was poor entrepreneurial culture. Moreover, in the Kashmir region there was lack of knowledge in the field of entrepreneurship. However, in the year 2004 JKEDI was constituted which to some extent flourished the entrepreneurship culture.

\subsection{Increasing Unemployment}

Unemployment had been the biggest issue in the state of Jammu and Kashmir. Despite the hefty flow of central government packages and regular incentives, the state governments remain 
incapable to deal with the unemployment. The state ranks first in the Northern region with regard to the unemployment. However, the largest numbers of educated youths has always found in the Kashmir valley. Hakhoo, S (2012) holds the same view "the number of unemployed youth registered in various District Employment and Counseling Centers is 6.01 lakhs ending September 2011, Economic Survey for the financial year 2011-12 has revealed. As per the figures, 3,21,562 youth have registered themselves in Kashmir region while the number is 2,80,285 in Jammu province. Out of the registered unemployed youth...more than 85,000 graduate and more than 20,000 post graduates....."6 had registered in the employment exchanges.

\subsection{Lack of Transport Facility}

Transport plays a significant role in the promotion of trade and business. However, the state of Jammu and Kashmir has hilly terrain areas, though the transport facility remained always weak. More particularly the Jammu region has well mettle roads, so the availability of transport becomes easy while the Kashmir region is far away (around $300 \mathrm{kms}$ ) from the Jammu region. The road connectivity is through the National Highway 1A from Jammu to Srinagar, but from the Jammu onwards the horrible, killer, destroyer hilly terrain starts. This hilly area road has become the cumbersome for the Kashmir valley. Besides this, the Jammu region had been connected through the railways with the rest of India while the railway line in the Kashmir region had been started in the year 1983. However, the actual formation to the railway line was given in the year 2002, when it was declared the national project and was supposed to complete in the year 2007. However, the national project missed the guidelines regularly and is still incomplete ${ }^{7}$.

\subsection{Limited Market}

In the competitive arena, the market plays an important role. However, in the state of Jammu and Kashmir there was a limited market. Moreover, in the Kashmir region the market remains only to the intra-districts of the Kashmir valley.

\subsection{Growing Horticulture Sector}

Agriculture sector had been the backbone of the state of Jammu and Kashmir. However, with the emergence of horticulture sector as the fast growing sector of the economy of the state of Jammu and Kashmir, the state's booming growth has been recognized at the national level. The growth of horticulture products had made the Kashmir region self-employed as it is the predominant sector of the region. Similarly, the Economic Survey of Jammu and Kashmir (2013-2014) states that "in Jammu and Kashmir State especially in Kashmir Division, horticulture plays a significant role in contributing to the development of the economy of the state. As per estimates, over 6 lac families are actively involved in horticulture sector. This sector is one of the most important employment generating sectors in the state. Year after year, there is a significant increase in area and production under horticulture crops..."8 


\section{Economic and Industrial Profile of Baramulla District}

Baramulla district economy lies mainly on the horticulture products. It is considered the largest producer and world-class Horticulture products (apple orchards) of the state of Jammu and Kashmir are produced in the district ${ }^{9}$.

Existing Status of Industries Areas in the District Baramulla

\begin{tabular}{|l|l|l|l|l|l|l|l|l|}
\hline $\begin{array}{l}\text { S.N } \\
0 .\end{array}$ & $\begin{array}{l}\text { Name of } \\
\text { Ind. Area }\end{array}$ & $\begin{array}{l}\text { Land } \\
\text { acquire } \\
\text { d (in } \\
\text { hectare } \\
\text { ) }\end{array}$ & $\begin{array}{l}\text { Land } \\
\text { develop } \\
\text { ed (In } \\
\text { Hect.) }\end{array}$ & $\begin{array}{l}\text { Prevaili } \\
\text { ng Rate } \\
\text { per } \\
\text { Sqm. } \\
\text { (In Rs.) }\end{array}$ & $\begin{array}{l}\text { No of } \\
\text { plots }\end{array}$ & $\begin{array}{l}\text { No of } \\
\text { allotted } \\
\text { Plots }\end{array}$ & $\begin{array}{l}\text { No of } \\
\text { vaca } \\
\text { nt } \\
\text { plots }\end{array}$ & $\begin{array}{l}\text { No of } \\
\text { units in } \\
\text { productio } \\
\text { n. }\end{array}$ \\
\hline 1. & I/E Bla. & 2.18 & 2.18 & NA & 17 & 17 & - & 16 \\
\hline 2 & I/E Sopore & 4.02 & 4.02 & NA & 44 & 29 & 15 & 12 \\
\hline & Total & 6.20 & 6.20 & - & 61 & 46 & 15 & 28 \\
\hline
\end{tabular}

The above table has been taken from the brief industrial profile of Baramulla district carried out by the MSME-Development Institute, J\&K, Jammu. The table shows the industrial profile of the Baramulla District. The data highlights that the industrial estates has been established in two main towns of the district- sopore town and Baramulla town. The data also shows that the industrial estate sopore has been allotted more land, highest number of plots, however, less number of units in production.

Details of Existing Micro \& Small Enterprises and Artisan Units in the District

\begin{tabular}{|c|c|c|c|c|}
\hline $\begin{array}{c}\text { NIC } \\
\text { CODE } \\
\text { NO. }\end{array}$ & TYPE OF INDUSTRY & $\begin{array}{c}\text { NUMBER OF } \\
\text { UNITS }\end{array}$ & $\begin{array}{c}\text { INVESTMENT } \\
\text { (lakh Rs.) }\end{array}$ & EMPLOYMENT \\
\hline 20 & Agro based & 201 & 685.00 & 625 \\
\hline 22 & Soda water & - & - & - \\
\hline 23 & Cotton textile & - & - & - \\
\hline 24 & $\begin{array}{c}\text { Woolen, silk \& artificial } \\
\text { thread based clothes. }\end{array}$ & - & - & - \\
\hline 25. & Jute \& jute based & - & - & 485 \\
\hline 26. & $\begin{array}{c}\text { Ready-made garments } \\
\text { embroidery }\end{array}$ & 161 & 110.00 & 521 \\
\hline 27. & $\begin{array}{c}\text { Wood/wooden based } \\
\text { furniture }\end{array}$ & 103 & 421.00 & 105 \\
\hline 28. & Paper \& Paper products & 35 & 125.00 & - \\
\hline 29. & Leather based & - & - & - \\
\hline 30. & $\begin{array}{c}\text { Rubber, plastic \& petro } \\
\text { based }\end{array}$ & - & - & - \\
\hline 31. & Chemical/chemical based & - & - & 1425 \\
\hline 32. & Mineral based & - & - & - \\
\hline 33. & Metal based (Steel Fab.) & 350 & 2450.00 & - \\
\hline 35. & Engineering units & - & - & 1410 \\
\hline 36. & $\begin{array}{c}\text { Electrical machinery and } \\
\text { transport equipments }\end{array}$ & - & - & - \\
\hline 97 & Repairing \& Servicing & 501 & 1855.00 & 577 \\
\hline 01. & Others & 62 & 1132.00 & - \\
\hline & Kachori Making. & - & 6778.00 & \\
\hline & $\quad 1413$ & & 5048 \\
\hline
\end{tabular}

Source: DIC Baramulla 
The above data shows that there is a great potential of the district Baramulla in flourishing the industrial units. According to the table, the agro-based industries have 201 established units, which is third highest after the Repairing and Services and Metal based.

\section{Ago-based Industry}

Agro-based industry could be defined as an industry that processes the raw material of agriculture, livestock, aquaculture, forests and horticulture in order into the processed items for convenient use of them in market which add an additional income to the products and profit to the manufacturer. In this context, the People's Democratic Party (PDP) and Congress coalition government (2002-2004) had come up a first detailed industrial policy on January 27, 2004 with the main objective to cope up with the regional industrial disparity in the state government of Jammu and Kashmir. The introduction of the policy states that "Despite attractive fiscal incentive under the State's Industrial Policy (1998-2003), the rate of growth of industrial sector could not be accelerated primarily on account of the disturbed conditions in the state. ...With the problem of unemployment, particularly of the educated, being high, the Industrial Policy 2004 has been evolved keeping in view the experience gained in the last five years and some new positive elements that have entered the scene".

During the coalition period (2002-2008) two agro-based industries have been established, one at Khunmooh (District Srinagar) and second at Doabegah (District Baramulla) with the assistance of MoFPI in the Kashmir region ${ }^{10}$. Similarly, the paper is analyzing the agro-based industry of Doabegah, Sopore area of Baramulla district. The industrial estate is having $82 \mathrm{kanals}^{11}$. Likewise, in the same area of the land has been allotted on the lease base for 90 years to 6 industrial units. Out of 6 industrial units only 2 are functional. Out of 2 functional units, the paper has been analyzing the one industrial unit i.e., Barkat Industries.

\section{Barkat Industries}

Barkat factory is locally known as 'Cardboard Factory' in the Kashmir valley as the industry manufactures the card board/apple boxes. Cardboard manufacturing is a new concept in the Kashmir region. The cardboards usage is for the protection of apples. Earlier the wooden manufactured boxes were used. However, with the growing horticulture products and insufficient amount of wooden boxes, card board boxes demand increased. It is comparatively less in amount then the wooden card boards. Similarly, local entrepreneur took an initiative to manufacture the card boards and 1Kanal land was allotted for the unit establishment in the same area on July 22, 2008. The raw material comes from both inside and outside state of Jammu and Kashmir. After manufacturing process the card boards came into market through the distributors. This unit is one among the two successful units which is in a position of growth. The detailed description of the said industry has been formulated in the tables. 
Table 1: General Information

\begin{tabular}{|l|l|l|l|l|}
\cline { 2 - 4 } \multicolumn{1}{c|}{} & Percentage of Gender Group & \multicolumn{1}{l|}{} \\
\hline Year & $\begin{array}{l}\text { Total } \\
\text { Employees }\end{array}$ & Male (\%) & Female (\%) & $\begin{array}{l}\text { Total } \\
\text { Production } \\
\text { In Lakhs }\end{array}$ \\
\hline 2011 & $23(100 \%)$ & $23(100 \%)$ & Nil & 4.5 \\
\hline 2012 & $17(73.91 \%)$ & $11(64.70 \%)$ & $06(35.30 \%)$ & 3.00 \\
\hline 2013 & $13(56.52 \%)$ & $07(53.85)$ & $06(46.15 \%)$ & 3.00 \\
\hline 2014 & $07(30.43 \%)$ & $07(100 \%)$ & Nil & 2.5 \\
\hline 2015 & $08(34.78 \%)$ & $08(100 \%)$ & Nil & 2.5 \\
\hline 2016 & $07(30.43 \%)$ & $07(100 \%)$ & Nil & 1.5 \\
\hline $\begin{array}{l}\text { Total } \\
\text { Workers }\end{array}$ & $\mathbf{7 5}$ & $\mathbf{6 3}$ & $\mathbf{1 2}$ & $\mathbf{1 7}$ \\
\hline
\end{tabular}

Source: Field Work

The table 1 shows that the Barkat industry starts its regular work since the year 2011 onwards. The employment percentage in the industry is more in male (84\%) while less in the females (16\%) and the female percentage had been reduced to zero percent from the year 2014 onwards. The data also shows that the regular employees/workers are going decreasing regularly by an estimated average of 12.5 employees. However, in the context of decreasing employees in the factory the total production also decreased abruptly at an estimated average of 2.833 lakhs.

Table 2: Qualification

\begin{tabular}{|l|l|l|l|l|l|l|}
\hline $\begin{array}{l}\text { Gender } \\
\text { Group }\end{array}$ & $\begin{array}{l}\mathbf{P . ~ G} \\
(\boldsymbol{\%})\end{array}$ & $\begin{array}{l}\text { Graduate } \\
(\boldsymbol{\%})\end{array}$ & $\begin{array}{l}\text { Under } \\
\text { Graduate } \\
(\boldsymbol{\%})\end{array}$ & $\begin{array}{l}\text { Senior } \\
\text { Secondary } \\
(\boldsymbol{\%})\end{array}$ & $\begin{array}{l}\text { Matric } \\
(\boldsymbol{\%})\end{array}$ & $\begin{array}{l}\text { Under-Matric } \\
(\boldsymbol{\%})\end{array}$ \\
\hline Male & --- & --- & --- & $16(21.33 \%)$ & $34(45.33 \%)$ & $13(17.33 \%)$ \\
\hline Female & --- & --- & --- & $08(10.67 \%)$ & $04(5.33 \%)$ & Nil \\
\hline $\begin{array}{l}\text { Total } \\
\text { Workers }\end{array}$ & ---- & ---- & --- & $\mathbf{2 4}$ & $\mathbf{3 8}$ & $\mathbf{1 3}$ \\
\hline
\end{tabular}

Source: Field Work

The table 2 shows that the industry has employed the lowest educated workers/employees. In the factory, the percentage of P.G, Graduate and Under Graduate is zero while the percentage of Senior Secondary is $(21.33 \%)$ in males on one hand and $(10.67 \%)$ in the females on the other hand. Similarly, the Percentage is lowest in the females (5.33\%) in the Matric and highest in the males (45.33\%). However, in the category of under-Matric, the males had been employed exclusively.

Table 3: Salary of Employees

Source: Field Work

\begin{tabular}{|l|l|}
\hline Pump Operator & 9,000 \\
\hline Foreman & 15,000 \\
\hline Sting Operator & 14,000 \\
\hline Other Male Employees & 9,000 \\
\hline Female Employees & 3500 \\
\hline Total Monthly Salary Expenditure & 50500 \\
\hline
\end{tabular}


The table 3 has been formulated, which shows the salary of the employees. In the similar context, foreman and sting operator has been given highest salary i.e., 15k and 14k respectively. However, the data reveals that the female employees has been given meager wages i.e., 3500, which is injustice and unsuitable for them. The lowest salary might be one among the reasons of the reduction of female employees in the industrial unit.

\section{Conclusion}

It can be said that the state government of Jammu and Kashmir has brought up the first detailed industrial policy for the state of Jammu and Kashmir. However, the industrial unit's position is going decline after every passing movement. This is a major concern for the Kashmir region so the state government has to take some measures to tackle the problem. This can't be done at the overnight but can seek out through the systematic way.

\section{Endnotes}

[1] For further reading see http://www.elections.in/jammu-and-kashmir/assembly-constituencies/2002-election-results.html.

[2] For further reading see Hassan, S. U et al (2015). Agriculture-Industry in the economy of Jammu and Kashmir India, Journal of Development and Agricultural Economics, Vol. 7(4), pp.174-181, Retrieved May 05, 2017 from http://www.academicjournals.org/journal/JDAE/article-full-textpdf/995FFAC51504.

[3] For further reading see Government of Jammu and Kashmir (2013-2014). Economic Survey, Directorate of Economics \& Statistics, Retrieved April 09, 2017 from J\&K http://www.indiaenvironmentportal.org.in/files/file/J\&K\%20EconomicSurvey\%202013-2014.pdf

[4] For further reading see http://kashmirreader.com/2014/01/13/kashmir-industry-discriminatedagainst-jammu-industrialists/

[5] For further reading see Entrepreneurship in India National Knowledge Commission 2008, Retrieved May 1, 2017 from http://knowledgecommissionarchive.nic.in/downloads/documents/NKC_Entrepreneurship.pdf

[6] For further reading see Hakoo, S (2012). JK has 6 lakh jobless youth, Greater Kashmir, Retrieved April , 2017 from http://www.greaterkashmir.com/news/news/jk-has-6-lakh-jobless-youth/114847.html

[7] For further reading see Kashmir rail link project to be completed by 2020: Railway officials, The Times of India, Retrieved April 11, 2017 from http://timesofindia.indiatimes.com/india/Kashmirrail-link-project-to-be-completed-by-2020-Railway-officials/articleshow/47938372.cms

[8] For further reading see Government of Jammu and Kashmir (2013-2014). Economic Survey, Directorate of Economics \& Statistics, Retrieved April 09, 2017 from J\&K http://www.indiaenvironmentportal.org.in/files/file/J\&K\%20EconomicSurvey\%202013-2014.pdf

[9] For further reading see http://baramulla.nic.in/WebPages/about/district_profile.html

[10] For further reading see http://foodprocessingindia.co.in/status-of-j-k-s-food-processing-industryj-k.html

[11] For further reading see http://dcmsme.gov.in/dips/dps\%20baramulla.pdf

\section{References}

[1] Chaudary, R (2016). Jammu and Kashmir Politics of Identity and Separatism, London New York, Routledge 
[2] Hassan, S. U et al (2015). Agriculture-Industry Linkages in the economy of Jammu and Kashmir India, Journal of Development and Agricultural Economics, Vol. 7(4), pp.174-181, Retrieved May 05, 2017 from http://www.academicjournals.org/journal/JDAE/article-full-textpdf/995FFAC51504

[3] Kachru, R. P. Agro-Processing Industries in India - Growth, Status and Prospects, Retrieved May 06, 2017 from http://www.panelamonitor.org/media/docrepo/document/files/agro-processingindustries-in-india-growth-status-and-prospects.pdf

[4] Kumar, R. S (2014). Studies on Prospects and Constraints of Agro-based Food Processing Industries in North East India, J. Agric. Technol., Vol. 1(2): 66-71, Retrieved May 06, 2017 from http://www.groupexcelindia.com/agriculture/agriculture_no_2/pdf/12.pdf

[5] Malik, F. A and Bilal A. M (2014). Politics of Coalition in India, Journal of Power, Politics \& Governance, March 2014, Vol. 2, No. 1, pp. 01-11, Retrieved April 15, 2017 from http://jppgnet.com/journals/jppg/Vol_2_No_1_March_2014/1.pdf

[6] Mohiuddin, S. and Hashia, H (2012). Regional socio-economic disparities in the Kashmir Valley (India) - a geographical approach, Bulletin of Geography. Socio-economic Series 18: pp 85-98, Retrieved December 01, 2016, from http://www.bulletinofgeography.umk.pl/18_2012/07_mohiuddin.pdf

[7] Rather, N. A, et al (2013). An Analytical Study on Production and Export of Fresh and Dry Fruits in Jammu and Kashmir, International Journal of Scientific and Research Publications, Vol. 3(2), Retrieved May 05, 2017 from http://www.ijsrp.org/research-paper-0213/ijsrp-p1484.pdf

[8] Reddy, C. L and S. Rathna, K (2014). Performance of Agro-Based Industries in India: A Critical Analysis, IOSR Journal of Economics and Finance (IOSR-JEF), Vol. 2(4): pp 15-25, Retrieved May 06, 2017 from http://www.iosrjournals.org/iosr-jef/papers/vol2-issue4/C0241525.pdf.

[9] Shejal, S. S (2013). Agro-based Industries and Rural Development, IJSR - International Journal of Scientific Research, Vol. 2(3), Retrieved May 01, 2017 from https://www.worldwidejournals.com/international-journal-of-scientific-research(IJSR)/file.php?val=March_2013_1362230777_c12da_31.pdf.

[10] Verma, P. S. (1987) 'Jammu and Kashmir Politics: Religion, Region and Personality Symbiosis', The Indian Journal of Political Science, 48(4): 561-574, Retrieved 13/01/2016 from https://www.jstor.org/stable/pdf/41855339.pdf

*Corresponding author.

E-mail address: gmohd28@yahoo.in 